AnNA NAPLOCHA

ORCID 0000-0003-1324-6125

Uniwersytet Zielonogórski

\title{
NIE TAKI WILK STRASZNY... O EDUKACJI EKOLOGICZNEJ W KONTEKŚCIE BAJKI WILK AMBARAS TOMASZA SAMOJLIKA I JEJ WPEYWIE NA KSZTAŁTOWANIE POSTAW PROEKOLOGICZNYCH DZIECI I MŁODZIEŻY WZGLĘDEM WILKÓW
}

\begin{abstract}
AвSTRAct. Naplocha Anna, Nie taki wilk straszny... O edukacji ekologicznej w kontekście bajki Wilk Ambaras Tomasza Samojlika i jej wptywie na kształtowanie postaw proekologicznych dzieci i młodzieży względem wilków [Not such a scary wolf... On Ecological Education in the Context of the Fable The Wolf Called Ambaras by Tomasz Samojlik and its Influence on Shaping Pro-Ecological Attitudes of Children and Adolescents Towards Wolves]. Studia Edukacyjne nr 53, 2019, Poznań 2019, pp. 321-340. Adam Mickiewicz University Press. ISSN 1233-6688. DOI: 10.14746/se.2019.53.18
\end{abstract}

This article deals with the issue of achieving the goals of ecological education in the context of the fable The Wolf Called Ambaras by Tomasz Samojlik and its influence on shaping pro-ecological attitudes of children and adolescents towards wolves. The fable The Wolf Called Ambaras by Tomasz Samojlik is part of the literature trend promoting pro-ecological attitudes within the framework of ecological education. The main educational goal included in the story of the fable treating the adventures of the young wolf is to provide young readers and their parents the knowledge about the wolves' life as well as public awareness of the need to protect the wolf by shaping positive attitudes of people towards this predator. Helpful in this assumption is taking up the problem of overthrowing negative stereotypes about wolves, on which the form of answers as well as attemption of demythologizing them are individual scenes of the fable. The plot of the analyzed fable attempts to answer the three main allegations of people towards wolves, which often appear in social, political and ecological discourse: the issue of wolves attacks on people, the impact of wolves hunting on forest game population and the public perception of a wolf as a bad animal, one unnecessary in the ecosystem. In addition, the bibliotherapeutic character of the fable was indicated. Through identificaiton with the character of the fable, readers can overcome their own fears related to their weaknesses and complexes based on the desensitization.

Key words: ecological education, wolves, fable, bibliotherapy 
Edukacja jest nierozerwalnie związana z podnoszeniem jakości życia oraz kwalifikacji przez osoby uczące się. Jak zauważa Magdalena Klaudia Terlecka, edukacja łączy się nie tylko z procesem kształcenia, rozumianym jako forma przekazywania wiedzy prowadzącej do rozwoju umiejętności, ale także $\mathrm{z}$ wychowaniem pojmowanym jako nabywanie postaw życiowych ${ }^{1}$. Aby osiągać zamierzone cele wpisane w system edukacyjny, należy realizować go w sposób dwutorowy: poprzez edukację formalną oraz edukację nieformalną.

Edukacja formalna to edukacja prowadzona w placówkach oświatowych, takich jak przedszkola, szkoły, uniwersytety oraz realizowana w trakcie profesjonalnych szkoleń, zgodnie z podstawą programową przygotowaną przez Ministerstwo Szkolnictwa i Nauki Wyższej. Natomiast edukacja nieformalna trwa przez całe życie człowieka, rozpoczyna się już od chwili urodzenia, jej pierwszym źródłem jest rodzina i najbliższe otoczenie. Edukację nieformalną prowadzą instytucje, organizacje, fundacje, stowarzyszenia pozarządowe i rządowe poprzez kampanie oraz akcje społeczne².

W związku z tym, że duży wpływ na edukację oraz rozwój dzieci i młodzieży w wieku szkolnym ma wpływ środowisko w jakim przebywają, ostatnimi czasy edukacja w wymiarze formalnym czy też nieformalnym podejmuje kwestie istotne społecznie $e^{3}$. „Ważnym obszarem zainteresowania społecznego stały się kwestie związane z uwarunkowaniami życia człowieka, a co się z tym łączy - ze środowiskiem jego funkcjonowania" ${ }^{4}$. W związku z postępującą technicyzacją życia, a także widoczną degradacją środowiska, coraz częściej podejmuje się na arenie społecznego dyskursu kwestie ekologii. Prymarnie, ekologia (termin wprowadzony oficjalnie do świata nauki w 1869 roku przez Ernsta Haeckela) związana stricte z naukami przyrodniczymi, „bada stosunki, zależności oraz związki zachodzące w przyrodzie pomiędzy czynnikami abiotycznymi i biotycznymi występującymi w środowisku" ${ }^{\prime 5}$. Obecnie

${ }^{1}$ M.K. Terlecka, O edukacji ekologicznej w Polsce, [w:] Edukacja ekologiczna. Wybrane problemy, red. M.K. Terlecka, Krosno 2014, s. 9.

${ }^{2}$ Tamże.

${ }^{3}$ Warto zwrócić uwagę na tematykę prowadzonych ostatnimi czasy zajęć o zasięgu ogólnokrajowym, m.in. akcje dotyczące szkoleń z udzielania pierwszej pomocy przedmedycznej, prelekcje prowadzone przez policjantów na temat uzależnień, pogadanki dotyczące edukacji seksualnej i przygotowania do życia w rodzinie, czy wreszcie zajęcia dotyczące kwestii ekologii, w tym m.in. segregowania odpadów podczas obchodów Światowego Dnia Ziemi.

${ }^{4}$ E. Kopeć, Znaczenie i rola edukacji ekologicznej w nauczaniu poczatkowym, [w:] Edukacja ekologiczna, s. 19.

${ }^{5}$ L. Tuszyńska, Edukacja ekologiczna dla nauczycieli i studentów, Warszawa 2006. Por. także definicję wprowadzoną przez Alinę Budniak, rozumiejącą ekologię jako dyscyplinę naukową, „określa się zazwyczaj jako naukę o związkach między organizmami lub grupami organizmów a środowiskiem albo jako naukę o współzależnościach pomiędzy żywymi organizmami a ich środowiskiem" (A. Budniak, Edukacja społeczno-przyrodnicza dzieci w wieku przedszkolnym i młodszym wieku szkolnym, Kraków 2014, s. 193). 
znaczenie terminu „ekologia” uległo rozszerzeniu o działania podejmowane w celu ochrony środowiska oraz kwestie związane z relacją człowiek - przyroda. Wzrost zainteresowania problemami środowiskowymi oraz pojawianie się licznych dyskusji na temat zagrożeń środowiskowych i ekologicznych spowodowały przyswojenie tych zagadnień przez różne dyscypliny naukowe ${ }^{6}$.

Kwestia ekologicznego podejścia do dobrodziejstw natury z poszanowaniem zasobów naturalnych (w szczególności tych nieodnawialnych) oraz problemy związane ze środowiskiem naturalnym stały się głównym tematem międzynarodowego dyskursu podczas I Międzynarodowej Konferencji UNESCO dotyczącej edukacji ekologicznej, która odbyła się w 1977 roku w Tbilisi. Jednym z głównych celów przyświecających spotkaniu było wypracowanie strategii rozwoju

obejmującego wiedzę, postawy, umiejętności, motywacje, a także obowiązek pracy indywidualnej i grupowej skierowanej ku rozwiązywaniu istniejących problemów [ekologicznych - przyp. A.N.] oraz ich zapobieganiu?

Edukacja ekologiczna - zamiennie nazywana środowiskową - oznacza koncepcję wychowania, przedmiot nauczania oraz działalność edukacyjno-wychowawczą, system kształtowania postaw i poglądów wobec otaczającego świata opartego na szacunku dla środowiska. Przez wieloaspektowe i interdyscyplinarne podejście: uwrażliwia na problemy i zagrożenia środowiskowe, uświadamia ich przyczyny i skutki, uczy metod ich rozwiązywania oraz odpowiedzialności za środowisko przyrodnicze, a także mobilizuje do czynnego podejmowania działań (osobistych i grupowych) na rzecz ochrony środowiska naturalnego ${ }^{8}$.

Edukacja ekologiczna9 stała się przedmiotem dyskursu zarówno w szkołach, jak i organizacjach pozarządowych, a zawód edukatora ekologicznego o uprawnieniach dydaktyczno-wychowawczych i doradczych został w Polsce oficjalnie wpisany pod numerem 325501 na listę Krajowego standardu kompetencji zawodowych Ministerstwa Pracy i Polityki Społecznej, Centrum Rozwoju Zasobów ${ }^{10}$. Na gruncie polskim „podstawa prawna edukacji ekologicznej za-

${ }^{6}$ M.K. Terlecka, O edukacji ekologicznej w Polsce, [w:] Edukacja ekologiczna, s. 9.

7 Zob. Przez edukacje do zrównoważonego rozwoju. Narodowa strategia edukacji ekologicznej, Ministerstwo Środowiska, Warszawa 2001.

${ }^{8}$ R. Olaczek, Stownik szkolny. Ochrona przyrody i środowiska, Warszawa 1999; L. Tuszyńska, Edukacja ekologiczna dla nauczycieli i studentów. Cyt. za: M.K. Terlecka, O edukacji ekologicznej w Polsce, [w:] Edukacja ekologiczna, s. 10.

${ }^{9}$ Jest to element postrzeganej w szerszym ujęciu edukacji środowiskowej, która uwzględnia nie tylko aspekty przyrodnicze, ale też aspekty społeczne i techniczne i dąży do wprowadzenia zasad rozwoju zrównoważonego (ekorozwoju). W Polsce edukacja środowiskowa nazywana jest wymiennie edukacją ekologiczną. Por. I. Jarzyńska, Edukacja ekologiczna w szkolnictwie szkolnym, Edukacja Elementarna w Teorii i Praktyce: kwartalnik dla nauczycieli, 2008, 1-2, s. 41.

${ }_{10}$ Klasyfikacja zawodów i specjalności na potrzeby rynku pracy (KZiS 2010), Krajowy standard kompetencji zawodowych Ministerstwa Pracy i Polityki Społecznej, Warszawa 2013. 
warta jest w Konstytucji RP, w Ustawach"11, a najważniejszym dokumentem poświęconym edukacji ekologicznej i regulującym jej cele dydaktyczno-wychowawcze jest Narodowa Strategia Edukacji Ekologicznej ${ }^{12}$. Do podstawowych celów dydaktyczno-wychowawczych edukacji ekologicznej zalicza się

objaśnianie jednostkom i społeczeństwom globalnego charakteru środowiska przyrodniczego, wynikającego $\mathrm{z}$ interpretacji naturalnych i sztucznych jego czynników (biologicznych, fizycznych, społecznych, ekonomicznych, kulturowych), opanowanie wiedzy, przyswojenie postaw i umiejętności, które pozwolą uczestniczyć w sposób odpowiedzialny i efektywny w skutecznym rozwiązywaniu obecnych i przyszłych problemów ekologicznych ${ }^{13}$.

Problematykę głównych celów edukacji ekologicznej podejmuje Magdalena Klaudia Terlecka ${ }^{14}$, która wzorując się na ustawach prawnych, w tym na Narodowej Strategii Edukacji Ekologicznej, wylicza następujące cele edukacji ekologicznej:

- kształtowanie pełnej i wieloaspektowej świadomości oraz budzenie zainteresowania powiązanymi kwestiami: społecznymi, politycznymi, ekonomicznymi i ekologicznymi;

- umożliwienie zdobywania i poszerzania wiedzy oraz umiejętności, które są konieczne dla ochrony środowiska i poprawy jego stanu;

- tworzenie proekologicznych wzorców zachowań oraz kształtowanie postaw, wartości i przekonań, które zapewnią troskę i możliwość ochrony środowiska;

- upowszechnianie idei rozwoju zrównoważonego we wszystkich sferach życia, uwzględniając: edukację, pracę i wypoczynek;

- objęcie edukacją ekologiczną wszystkich obywateli Rzeczpospolitej Polskiej;

- wdrożenie edukacji ekologicznej jako edukacji interdyscyplinarnej na etapach edukacji formalnej i nieformalnej;

- tworzenie programów edukacji ekologicznej na szczeblach administracyjnych na poziomie: województw, powiatów i gmin;

- promowanie dobrych metod, pomysłów i doświadczeń z zakresu metodyki i edukacji ekologicznej ${ }^{15}$.

Edukacja ekologiczna oprócz wdrażania informacji i dzielenia się wiedzą na tematy związane ze środowiskiem naturalnym, ukierunkowana jest przede wszystkim na wypracowanie pewnych wzorców zachowań u odbiorcy, do którego skierowane są działania o charakterze proekologicznym. Jedynie holistyczne ujęcie procesu edukacji ekologicznej nastawione na przekaza-

\footnotetext{
11 M.K. Terlecka, O edukacji ekologicznej w Polsce, [w:] Edukacja ekologiczna, s. 10-11.

12 Narodowa Strategia Edukacji Ekologicznej, Warszawa 2001.

13 I. Jarzyńska, Edukacja ekologiczna, s. 42.

14 M.K. Terlecka, O edukacji ekologicznej w Polsce, [w:] Edukacja ekologiczna, s. 12.

15 Tamże.
} 
nie wiedzy i stwarzanie warunków do wychowania jest gwarantem postawy świadomego poszanowania przyrody i dążenia do przestrzegania zasad zrównoważonego rozwoju.

Przyroda jest (...) nie tyle dana, ile zadana (...). Życie przyrody wymaga innego życia człowieka, życie biologiczne apeluje do życia ludzkiego - świadomego wartości swojego życia ${ }^{16}$.

Owa świadomość istotnych problemów ekologicznych jest objawem rozwiniętej osobowości ekologicznej człowieka, którego charakteryzuje

(...) uczciwość i tolerancja, całościowy sposób widzenia świata, życzliwa postawa wobec wszystkich żywych istot, wrażliwość na piękno Ziemi, a zarazem gotowość i umiejętność działania w obrębie jej praw oraz tryb życia zgodny z hierarchią wartości ekologicznych ${ }^{17}$,

a także gotowość do podejmowania działań zmierzających do ochrony środowiska $^{18}$. Wskazane jest, aby edukacja ekologiczna w stopniu dostosowanym do wieku odbiorcy była prowadzona na wszystkich szczeblach edukacyjnych, a także poza nimi w ramach idei uczenia się przez całe życie (lifelong learning). Oprócz niekwestionowanej wartości aktywnych metod stosowanych w edukacji ekologicznej, do której zalicza się między innymi czynny udział w wycieczkach szkolnych ${ }^{19}$, przygotowywanie „kącika przyrody” przez dzieci, czy udział w zajęciach laboratoryjnych, coraz większe uznanie zdobywają bierne metody edukacji.

Bierne metody edukacji opierają się głównie na działalności wydawniczej, opracowaniach multimedialnych, tworzeniu ścieżek dydaktycznych i uczestnictwie w wystawach oraz konkursach, dominuje w nich aspekt wiedzotwórczy, nie ma jednak gwarancji, że będą one oddziaływać na postawy ${ }^{20}$.

${ }^{16}$ L. Domka, Dialog z przyroda w edukacji dla ekorozwoju, Warszawa - Poznań 2001, s. 86.

17 S. Wajchman, W. Borzyszkowski, P. Matulewski, Rola edukacji przyrodniczo-leśnej w kształtowaniu proekologicznych postaw społeczeństwa, [w:] Edukacja ekologiczna, s. 128-129. Zob. A. Kalinowska, Ekologia - wybór przyszłości, Warszawa 1993.

18 A. Pawłowski, Rozwój zrównoważony - idea, filozofia, praktyka, Monografie Komitetu Inżynierii Środowiska PAN, 2008, 51, Lublin.

${ }_{19}$ Zob. M. Fiszer, Metody i formy w edukacji ekologicznej dzieci w wieku przedszkolnym, Prace Naukowe. Pedagogika, 2002, 11, s. 37. „Obcowanie z przyrodą, uważa się za najlepszą drogę do zdobywania wiedzy oraz główne źródło wyobrażeń o niej. Dziecko uczy się dokładnej, usystematyzowanej obserwacji, odkrywania zależności w świecie przyrody, rozumienia zjawisk, kształtowania przyjaznych postaw wobec przyrody". Por. I. Buczyńska, K. Chojecka, E. Rozpądowska, Przedszkolaki blizej natury, Wychowanie w Przedszkolu, 1999, 7, s. 528.

${ }^{20}$ S. Wajchman, W. Borzyszkowski, P. Matulewski, Rola edukacji przyrodniczo-leśnej, s. 128129. 
Bierne metody edukacyjne, w których wykorzystuje się pomoce naukowe $\mathrm{w}$ formie książek czy opracowań multimedialnych mogą być stosowane $w$ trakcie edukacji nieformalnej dzieci oraz osób dorosłych.

Jednym z przykładów zastosowania biernej metody w edukacji ekologicznej jest wykorzystanie bajek przygotowanych z myślą o najmłodszych odbiorcach. Bajka to

jeden z podstawowych gatunków dydaktycznej literatury; krótka powiastka wierszowana lub prozą, której bohaterami są zwierzęta, ludzie, rzadziej rośliny lub przedmioty, zawierająca moralne pouczenie wypowiedziane wprost lub dobitnie zasugerowane ${ }^{21}$.

Magdalena Rybczyńska ${ }^{22}$ wymienia zalety wykorzystywania tego gatunku literackiego w edukacji dzieci:

[bajki - przyp. A.N.] są niezwykle cenne dla wspomagania prawidłowego rozwoju dziecka w wieku wczesnoszkolnym. Bajki rozszerzają też świat myśli dziecka, oferują mu przeżycia, jakich do tej pory nie zaznało $\mathrm{w}$ świecie zabaw, umożliwiają mu zdobycie wiedzy o rzeczach nieznanych. Właściwie dobrane bajki rozszerzają niesłychanie zakres doświadczeń dziecka. I choć chodzi tu o doświadczenia fikcyjne, są one bardzo kształcące i potrzebne dla pełnego rozwoju duchowego dziecka. Bajki i baśnie od zawsze były chętnie słuchane przez dzieci oraz opowiadane im i czytane przez rodziców. Stanowią one pierwsze lektury w życiu dziecka, niejednokrotnie rozbudzając na całe życie jego zainteresowania czytelnicze. (...) Badania psychologiczne i pedagogiczne dowiodły, że lektura baśni i bajek pełni niezwykle istotną funkcję w życiu dziecka, przyczyniając się do jego wszechstronnego rozwoju ${ }^{23}$.

Oprócz dostarczania przeżyć emocjonalnych i estetycznych, lektura bajek stanowi także duży potencjał terapeutyczny. Bajkoterapia jako element szerzej pojętej biblioterapii jest środkiem do mówienia dziecku poprzez świat przedstawiony w utworze o rzeczach trudnych do przyjęcia czy kłopotliwych w wytłumaczeniu. Dziecko identyfikując się z postawami bohaterów bajek, przeżywa przygody swoich ulubionych postaci i przyjmuje morał płynący z fabuły dydaktycznej bajki. Identyfikacja dziecka z postaciami występującymi w bajce jest wykorzystywana w narracji bajek terapeutycznych, w których za pomocą słowa leczy się lub zapobiega rozwijającym się dysfunkcjom dziecka na zasadzie odwrażliwienia ${ }^{24}$.

${ }^{21}$ Hasło 'bajka', [w:] Słownik terminów literackich, red. J. Sławiński, Wrocław - Kraków 1998, s. 55 .

${ }^{22}$ M. Rybczyńska, Rola bajki w XXI wieku w stymulowaniu rozwoju dziecka w wieku wczesnoszkolnym 7-10 lat, Kultura i Historia, 2017, 32, s. 263-271.

${ }^{23}$ Tamże, s. 269.

${ }^{24}$ Tamże, s. 267: „Wyśmienitym przykładem bajki, która redukuje lęk są opowieści o ryjówce Florce autorstwa R. Jędrzejewskiej-Wróbel. Główna bohaterka bajeczki «Florka z pamiętnika ryjówki» $\mathrm{w}$ zeszycie otrzymanym w prezencie od taty prowadzi zapiski doty- 
Bogusław Żurakowski w pracy dotyczącej wartości estetycznych w literaturze dla dzieci ${ }^{25}$ stwierdza, że:

świadomość dziecka wychowującego się w stechnicyzowanym świecie i poddawanego oddziaływaniu światopoglądu naukowego wykazuje się mitycznością, a tym samym okazuje zapotrzebowanie na tego typu literaturę. Brak sfery mitu w utworach adresowanych do dzieci może spowodować wzmożenie spontanicznego, wyłączonego spod kontroli mitotwórstwa ${ }^{26}$.

W związku z dominującą funkcją edukacyjną bajek i podatnością wyobraźni dzieci na treści w nich przedstawione, na rynku wydawniczym pojawiły się bajki uwrażliwiające młodych czytelników na tematykę ekologiczną ${ }^{27}$. Jak zauważa Radosław Niziołek,

powstało wiele opracowań poświęconych edukacji ekologicznej. Autorzy tych publikacji mają nadzieję, że wplatając wątek ekologiczny do bajki, będą w stanie przekonać swoich najmłodszych odbiorców do praktyk proekologicznych (...) Najlepsze skutki biblioterapii są możliwe do osiągnięcia poprzez wczesne wprowadzanie dziecka do świata ekologii, zaczynając od wspólnego czytania bajek, a kończąc na nawyku czytania książek ${ }^{28}$.

Jedną z bajek o treści ekologicznej przeznaczonej dla czytelnika w wieku szkolnym $^{29}$ jest bajka autorstwa Adama Samojlika ${ }^{30}$, opowiadająca o przy-

czące wszystkich ważnych dla niej spraw, choć dopiero niedawno nauczyła się pisać i czytać" (R. Jędrzejewska-Wróbel, Florka - z pamiętnika ryjówki, Łódź 2008).

${ }_{25}$ B. Żurakowski, Wartości estetyczne w literaturze dla dzieci, [w:] Wartości w świecie dziecka i sztuki dla dzieci, red. M. Tyszkowa, B. Żurakowski, Warszawa - Poznań 1984, s. 205-231.

${ }^{26}$ Tamże, s. 213. Por. P. Kowolik, Wptyw bajki i baśni na dzieci w edukacji wczesnoszkolnej: szkic teoretyczny, Nauczyciel i Szkoła, 2004, 3-4 (24-25), s. 37-52.

${ }_{27}$ Zob. bajki o tematyce ekologicznej dla przedszkolaków, np. B.B. Jadach, Kolorowe kosze. Bajki o tematyce ekologicznej, Warszawa 2014.

${ }^{28}$ R. Niziołek, Promocja ekologii wśród dzieci i młodzieży na przykładzie programu telewizyjnego «Załoga Eko», Studia i Materiały CEPL w Rogowie, 2015, 17, 43(2), s. 94-95.

${ }^{29}$ W związku z podaną przez Magdalenę Rybczyńską zależnością między wiekiem dziecka a wykazywanymi przez niego umiejętnościami językowymi i poznawczymi, można uznać, że fabuła dydaktyczna bajki o wilku Ambarasie jest dostosowana językowo i stylistycznie dla dzieci zdecydowanie powyżej siódmego roku życia. Zob. M. Rybczyńska, Rola bajki w XXI wieku, s. 264: „Okres między siódmym a dziesiątym rokiem życia jest niezwykle istotny w rozwoju dziecka. Wymaga mądrej i przemyślanej stymulacji, polegającej na dostarczaniu bodźców wzmacniających dojrzewanie w sferze psychicznej, emocjonalnej, intelektualnej, społecznej i moralnej. Jednym z czynników służących rozwojowi dziecka są bajki, rozumiane jako teksty kultury przeznaczone dla dzieci".

${ }^{30}$ Tomasz Samojlik - pracownik Instytutu Biologii Ssaków Polskiej Akademii Nauk w Białowieży, który prowadzi także działalność edukacyjną. Jest autorem (treści i ilustracji) cyklu bajek dla dzieci dotyczących ekologii Puszczy Białowieskiej - Żubr Pompik (T. Samojlik, Żubr Pompik. Tropy na śniegu, Poznań 2016; Żubr Pompik. Zapach wiosny, Poznań 2016; Żubr Pompik: Letni zmierzch, Poznań 2016; Żubr Pompik. Kolory jesieni, Poznań 2016); oraz serii Żubr Pompik. 
godach wilka (Canis lupus) o imieniu Ambaras ${ }^{31}$. Pretekstem do napisania bajki traktującej o wilku - pomimo objęcia tego zwierzęcia od 1998 roku ochroną gatunkową na terenie całej Polski ${ }^{32}$ - jest nadal obecne $\mathrm{w}$ społeczeństwie stereotypowe, negatywne postrzeganie tego drapieżnika. Główny przekaz kulturowy ${ }^{33}$ dotyczący wilka przedstawia go jako symbol zła, chciwości. Wilk jest

symbolem nienasyconej żarłoczności i żądzy mordu, postrachem pasterzy i myśliwych; jego wycie, a bardziej jeszcze jego pojawienie się uważano za zły albo śmiertelny omen; ustawiczne wędrówki wilka łączyły go w wyobraźni ludowej z uciekiniera$\mathrm{mi}$, banitami i porzuconymi dziećmi ${ }^{34}$.

Ponadto, strategia łowiecka tego gatunku, charakteryzująca się upatrywaniem swych ofiar także wśród zwierząt gospodarskich, powoduje postrzeganie wilka za gatunek konfliktowy, szczególnie wśród mieszkańców południowo-wschodniej Polski, gdzie notabene występuje największe zagęszczenie

Wyprawy (T. Samojlik, Tajemnica rzeki, Poznań 2017; Bagienny łoś, Poznań 2017; Plan bobra, Poznań 2017; Rodzina borsuków, Poznań 2018).

31 T. Samojlik, Wilk Ambaras, Warszawa 2012.

${ }^{32}$ Zob. Status prawny wilka, Stowarzyszenie dla Natury „Wilk” http://www.polskiwilk. org.pl/status-prawny-wilka [dostęp: 20.11.2018]:

"W roku 1995 wilki zostały objęte ochroną w części Polski, a od 1998 są chronione w całym kraju. W uzasadnieniu do tej decyzji podkreślono pozytywną rolę drapieżników w utrzymaniu równowagi ekologicznej $\mathrm{w}$ lasach. Obecny status prawny wilka reguluje Ustawa z 16 kwietnia 2004 r. o ochronie przyrody (tekst jednolity DzU z 2013, poz. 627, z późniejszymi zmianami) oraz Rozporządzenie Ministra Środowiska z 16 grudnia 2016 r. w sprawie ochrony gatunkowej zwierząt (DzU 2016, poz. 2183). Zgodnie z nimi, wilki objęte są ochroną ścisłą. Zabronione jest ich zabijanie, okaleczanie, chwytanie, przetrzymywanie, niszczenie nor i wybieranie z nich szczeniąt, a także przechowywanie i sprzedaż skór oraz innych fragmentów martwych osobników, bez odpowiedniego zezwolenia. Ponadto, można tworzyć dla nich strefy ochronne wokół miejsc rozrodu (nor) od 1 kwietnia do 31 sierpnia. Powyższe zakazy nie dotyczą sytuacji, gdy konieczne jest schwytanie zwierząt rannych i osłabionych, $\mathrm{w}$ celu udzielenia im pomocy weterynaryjnej i przemieszczenia do ośrodka rehabilitacji, a także kiedy trzeba odłowić zwierzę, które zabłąkało się w pobliże siedzib ludzkich, i przenieść je do miejsca jego regularnego przebywania. Nierespektowanie zapisów prawa podlega karze aresztu lub grzywny. W szczególnych przypadkach możliwe są odstępstwa od powyższych zakazów na podstawie zezwolenia wydanego przez Generalnego Dyrektora Ochrony Środowiska. Nierespektowanie zapisów Ustawy podlega karze aresztu lub grzywny. Wilk jest wymieniony w Załączniku II Dyrektywy Siedliskowej UE. Oznacza to, że jest gatunkiem wyznacznikowym dla typowania obszarów Natura 2000 - ma on tu status gatunku priorytetowego. Chroniony jest również przez Konwencję Berneńską. W «Polskiej czerwonej księdze zwierząt» wilk ma status NT (near threatened) - gatunek niższego ryzyka, ale bliski zagrożenia".

${ }^{33}$ Przez pojęcie przekazu kulturowego dotyczącego wilków rozumie się m.in. dzieła literackie, filmowe, czy tradycję ludową podejmującą treści związane z wizerunkiem wilka i sposobem postrzegania go przez daną społeczność.

${ }^{34}$ Zob. Hasło 'wilk', [w:] W. Kopaliński, Stownik mitów i tradycji kultury, Warszawa 1985, s. 1286. 
populacyjne Canis $\operatorname{lupus}^{35}$ i dochodzi do częstszych ataków wilków na zwierzęta gospodarskie ${ }^{36}, \mathrm{w}$ porównaniu z pozostałymi rejonami kraju. A także, w środowisku myśliwych rodzą się obawy, jaki wpływ będzie wywierać rosnąca populacja wilków na inne zwierzęta leśne, głównie na populacje sarny, dzika, czy jelenia, które stanowią bazę żywieniową wilków. Jednym z podstawowych, ale i priorytetowych założeń mających na celu zmianę postrzegania wilka w Polsce (i tym samym niedopuszczenia do sytuacji mającej miejsce w latach 60. XX wieku, kiedy dochodziło do powszechnej eksterminacji gatunkowej wilka na terenie Polski) jest przybliżanie obywatelom wiedzy na temat życia tych drapieżników i podkreślenia ich ważnej roli w zachowaniu równowagi ekosystemu. Jak zauważają autorzy projektu Program ochrony wilka «Canis lupus» w Polsce ${ }^{37}$ :

Różnego rodzaju przedsięwzięcia i inicjatywy o charakterze edukacyjnym są ważnym sposobem zwiększenia świadomości społecznej na temat dużych drapieżników, co powinno w konsekwencji prowadzić do podniesienia poziomu akceptacji tych zwierząt. Znaczenia tych działań nie można jednak przeceniać i traktować ich, jako jedyne, któ-

${ }^{35}$ Zob. I. Wierzbowska, Rozmieszczenie wilków w Polsce i na świecie oraz środowisko życia, [w:] I. Wierzbowska, Wilk, Kraków 2010, s. 33: „Wilki występują przede wszystkim w Polsce północno-wschodniej, wschodniej i południowej. Najliczniejsze są w Karpatach (w paśmie Bieszczady - Beskid Śląski) oraz w Pogórzu Karpackim, ok. 250 osobników. Kolejne obszary o dużym zagęszczeniu wilków to Lasy Napiwodzko-Ramuckie i Puszcza Piska, Puszcza Białowieska, Puszcza Knyszyńska. W Polsce, w sezonie 2008/2009, zinwentaryzowano ok. 140 watah. Średnia liczba osobników przypadająca na watahę wynosiła 4,9". Terytorium występowania wilka obejmuje również tereny Polski zachodniej, gdzie od roku 2001 następuje stopniowa rekolonizacja tych ziem: „Badania wilków prowadzono od roku 2001 do zimy 2012/2013 we wszystkich większych kompleksach leśnych na zachodzie kraju, m.in. w puszczach: Piaskowej (Cedyński Park Krajobrazowy), Goleniowskiej, Drawskiej, Bydgoskiej, Noteckiej i Rzepińskiej, a także na terenie lasów: Koszalińskich, Wałeckich, Sarbskich oraz w Borach Tucholskich i Dolnośląskich". Zob. A. Ślązak, Raport: wilki w Polsce Zachodniej mają się coraz lepiej, PAP:

http:/ / naukawpolsce.pap.pl/aktualnosci/news\%2C408470\%2Craport-wilki-w-polscezachodniej-maja-sie-coraz-lepiej.html [dostęp: 20.11.2018].

${ }^{36}$ H. Okarma, R. Gula, P. Brewczyński, Konflikt wilków z człowiekiem. Konflikt z hodowla zwierząt gospodarskich [w:] H. Okarma, R. Gula, P. Brewczyński, Program ochrony wilka Canis lupus $w$ Polsce - Projekt Krajowa strategia ochrony wilka warunkujaca trwałość gatunku w Polsce, Warszawa 2011, s. 31: „W 2005 r. na zamówienie Ministerstwa Środowiska wykonano opracowanie «Analiza dotychczasowych rodzajów i rozmiaru szkód wyrządzanych przez wilki (Canis lupus) oraz stosowanie metod rozwiązywania sytuacji konfliktowych» (...) Stwierdzono wtedy, że w latach 2000-2003 ataki wilków na inwentarz wystąpiły w województwach: podlaskim, warmińsko-mazurskim, mazowieckim, podkarpackim, małopolskim, śląskim i lubelskim. Wśród ofiar drapieżników najwięcej było owiec i bydła. Zdecydowanie mniej zostało zabitych kóz i psów, a tylko sporadycznie ginęły konie oraz hodowlane jelenie i daniele. Zob. S. Nowak i in., Analiza dotychczasowych rodzajów i rozmiaru szkód wyrządzanych przez wilki (Canis lupus) oraz stosowanych metod rozwiazywania sytuacji konfliktowych, 2005 (manuskrypt).

${ }_{37}$ H. Okarma, R. Gula, P. Brewczyński, Działania niezbędne dla realizacji celów strategii. Dziatania informacyjne/edukacyjne/komunikacyjne, [w:] H. Okarma, R. Gula, P. Brewczyński, Program ochrony wilka Canis lupus w Polsce, s. 67. 
re mogą poprawić stan ochrony wilka, rysia i niedźwiedzia. Muszą one być wdrażane jako przedsięwzięcia komplementarne do aktywnych działań zarządzania gatunkiem (...) Działania edukacyjne i komunikacyjne nie powinny być prowadzone tylko przez organizacje społeczne i instytucje naukowe, jak to zwykle miało miejsce do tej pory, ale przede wszystkim przez rządowe i samorządowe instytucje zajmujące się rolnictwem i ochroną przyrody, tj. Ministerstwo Rolnictwa i Rozwoju Wsi, Ministerstwo Środowiska, GDOŚ/RDOŚ, ośrodki doradztwa rolniczego, służby ochrony przyrody itd. ${ }^{38}$

Ponadto, jak zauważają autorzy artykułu traktującego o wynikach ankiety przeprowadzonej na temat wiedzy o wilkach wśród pełnoletnich mieszkańców wybranych miast i wsi północno-zachodniej Polski w roku 2016 ${ }^{39}$,

(...) tylko edukacja całościowa - obejmująca zdobywanie wiedzy z różnych dziedzin życia oraz obejmująca całokształt wiedzy o środowisku i ciągła - trwająca całe życie, ma szanse wpłynąć na postawy społeczne ${ }^{40}$.

Jednym ze sposobów mających wpłynąć na zmianę postrzegania wilka jako gatunku pożytecznego jest edukacja ekologiczna prowadzona od najmłodszych lat. Przykład tego typu przedsięwzięć proekologicznych stanowi wydanie bajki traktującej o przygodach wilka o imieniu Ambaras. Z jej fabuły dydaktycznej najmłodsi czytelnicy dowiadują się w przystępny sposób o życiu wilczej watahy, strukturze stada, instynkcie łowieckim, czy relacjach wilków z ludźmi. Jak podkreśla Stefan Jakimiuk ${ }^{41}$ - kierownik projektu WWF „Białowieski Park Narodowy” która jest wydawcą ${ }^{42}$ książki autorstwa Tomasza Samojlika o wilku Ambarasie - głównym celem dydaktycznym powstałej bajki jest chęć przełamania stereotypowego, najczęściej negatywnego sposobu postrzegania wilka w społeczeństwie: „Mam nadzieję, że ta mądra opowieść stanie się obowiązkową lekturą wszystkich dzieci i ich rodziców, a «straszne historie o wilkach» odejdą w zasłużone zapomnienie" ${ }^{43}$. Podobnie jak to

38 Tamże.

39 A. Wierzbicka i in., Do kogo kierować edukację? Wiedza społeczeństwa na temat wilków w pótnocno-zachodniej Polsce, Studia i Materiały CEPL w Rogowie, 2016, 18, 47(2), s. 136-139.

40 Tamże, s. 136 i 139: „(...) wysuwa jednak wniosek, iż nastawienie do poszczególnych gatunków oraz działań pro środowiskowych wynika w większym stopniu z emocji niż z wiedzy. Emocje zaś buduje bezpośrednie doświadczenie. Dlatego warto się zastanowić czy edukacja, także osób dorosłych, nie powinna iść w stronę bezpośredniego przebywania w lesie, niż przekazywania wiedzy jak to postuluje Louv (R. Louv, Ostatnie dziecko lasu, Warszawa 2014) w odniesieniu do dzieci".

41 Stefan Jakimiuk - biolog, od 2001 roku kierownik projektu WWF „Białowieski Park Narodowy".

42 „Wydanie książki sfinansowane w ramach projektu Ochrona gatunkowa rysia, wilka i niedźwiedzia w Polsce przy dofinansowaniu ze środków Mechanizmu Finansowego Europejskiego Obszaru Gospodarczego oraz Norweskiego Mechanizmu Finansowego". Nota na stronie tytułowej, [w:] T. Samojlik, Wilk Ambaras, s. 2.

43 S. Jakimiuk, Stowo od wydawcy, [w:] Tamże, s. 3. 
miało miejsce w konstrukcji fabularnej bajek o żubrze Pompiku, prowadzona $\mathrm{w}$ formie prozy narracja o wilczych przygodach jest okazją do poznania przez czytelników zwyczajów także innych mieszkańców lasu.

Książka „Wilk Ambaras”, to niezwykła historia małego wilczka i jego wilczej rodziny. Choć napisana jest w konwencji bajki, to wiele mówi o prawdziwym życiu wilków, o roli jaką pełni w przyrodzie oraz trudnych relacjach między człowiekiem a jednym z najwspanialszych drapieżników żyjącym współcześnie na Ziemi ${ }^{44}$.

Warto zastanowić się, jakie informacje z dziedziny biologii i etologii Canis lupus zostają przedstawione w historii o wilku Ambarasie oraz jakie stereotypy na temat wilków podlegają w niej demitologizacji? Fabuła bajki dzieli się na dziesięć rozdziałów. W każdym z nich młody czytelnik zapoznaje się z informacjami i ciekawostkami na temat życia wilków, które są wplecione w ciąg fabularny opowieści napisanej w konwencji przygodowej. W związku z tym, że głównym celem edukacji, w tym edukacji ekologicznej, jest przekazywanie wiedzy i kształtowanie postaw życiowych, warto zastanowić się, w jaki sposób poprzez treść bajki na temat wilków zrealizowane zostały te dwa główne cele edukacyjne?

Jednym z głównych celów, jakim jest przekazanie wiedzy opartej na lekturze bajki, stanowi uświadomienie czytelnika w kwestiach dotyczących biologii i etologii wilka. W związku z tym, że głównymi adresatami utworu są dzieci i młodzież w wieku szkolnym (choć wśród potencjalnych odbiorców wzmiankowani są także rodzice ${ }^{45}$ ), treści te są dostosowane do ich wieku i możliwości poznawczych. Najwięcej informacji na temat struktury watahy porównanej w utworze do ludzkiej rodziny (tata-basior: Krzepki; mama-wadera: Ruda; rodzeństwo Ambarasa ze starszego miotu: Białka, Smuga, Kieł; rodzeństwo Ambarasa z jednego miotu: Chyży, Mocarny; dziadek-piastun: Kulawiec, który okazuje się legendarnym wilkiem Czortem) znajduje się w rozdziale pierw$\mathrm{szym}^{46}$. Fabuła bajki obejmuje niecały rok z życia wilczego stada: rozpoczyna się wiosną, kiedy wilczki przychodzą na świat, i kończy z nadejściem zimy, kiedy młode wilki, $w$ tym tytułowy Ambaras, są samodzielnymi szczeniętami. Zbudowanie fabuły opartej na zmieniających się porach roku stanowi okazję do przedstawienia czytelnikom charakterystycznych cech każdej z nich, co doskonale podkreśla cykliczność i zależność między jakością życia zwierząt a występującymi porami roku. Poprzez poznawanie wilczych przygód w ciągu niecałego roku, czytelnik ma okazję do zapoznania się z etapami rozwoju

\footnotetext{
44 Tamże.

45 Tamże: „Mam nadzieję, że ta mądra opowieść stanie się obowiązkową lekturą wszystkich dzieci i ich rodziców".

${ }^{46}$ T. Samojlik, Rozdziat pierwszy, w którym pewien stabowity wilczek przychodzi na świat $i$ otrzymuje kłopotliwe imię, [w:] T. Samojlik, Wilk Ambaras, s. 7-17.
} 
szczeniąt, a przez to zdobywa wiedzę na temat biologii i etologii tego gatunku. Ponadto, młody czytelnik $w$ trakcie lektury bajki poznaje role, jakie odgrywają poszczególne wilki w stadzie, gdzie na przykład roli piastuna opiekującego się młodymi wilkami podczas nieobecności członków stada odpowiada rola dziadka w ludzkiej rodzinie, który także opiekuje się wnuczętami i służy im radą. Czytelnik z lektury bajki może dowiedzieć się również o zachowaniu tych drapieżników: jak wilki polują, albo co to znaczy, że sznurują ${ }^{47}$. Przygody wilka Ambarasa są także pretekstem do edukacji ekologicznej na temat innych mieszkańców lasu, na przykład tajemniczego gryzonia - orzesznicy ${ }^{48}$ (Muscardinus avellanarius) Łupinki, czy młodego dzika ${ }^{49}$ (Sus scrofa) Niucha - przyjaciół Ambarasa. Fabuła zbudowana jest na podstawie zagadek zadawanych przez orzesznicę, które musi rozwiązać tytułowy bohater bajki, co może okazać się interesujące dla stawiającego nieraz podobne pytania młodego czytelnika i pozwala mu utożsamić się z bohaterami bajki. Wraz z wilkiem Ambarasem poznającym las o każdej porze roku, można dowiedzieć się między innymi, czym sierść młodych osobników różni się od sierści osobników dorosłych, jaką rolę w życiu zwierząt odgrywa kamuflaż, kto sadził drzewa w lesie przed pojawieniem się człowieka, a także dlaczego dzięcioł umieszcza szyszki w korze dębu na podobieństwo kuźni ${ }^{50}$ ? Ponadto, w bajce przedstawiona zostaje problematyka polowań na wilki, zastawiania na nie wnyków, a czytelnicy mają okazję poznać historię prześladowań wilków, o których opowiada nestor wilczej familii - Kulawiec (Czort) ${ }^{51}$.

${ }^{47}$ Sznurowanie - jeden ze sposobów przemieszczania się wilków, charakteryzujący się ułożeniem tropów w jedną linię; wilk idący za poprzedzającym go osobnikiem stawia łapy idealnie w miejsce tropów już przez niego pozostawionych. Niezależnie od liczebności przemieszczającego się stada, wataha pozostawia za sobą tylko jeden trop dający złudzenie jakoby przechodził tamtędy tylko jeden wilk.

${ }^{48}$ Orzesznica leszczynowa, daw. orzesznica - gatunek niewielkiego, rudego gryzonia z rodziny popielicowatych, jedynego przedstawiciela rodzaju orzesznica (Muscardinus), mieszkającego w lasach. Żywi się orzechami, jagodami i żołędziami.

${ }^{49}$ Dzik - jedyny wszystkożerny przedstawiciel dziko żyjących świniowatych w Europie jest przodkiem świni domowej.

${ }^{50}$ Kuźnia dzięcioła - „Dzięcioł duży głównie żywi się owadami i ich larwami wydobywanymi z pni drzew. W menu ptaka (...) znajdują się także jagody i orzechy laskowe. Zimą, kiedy drewno jest zbyt twarde lub w lata ubogie w owady, ratuje się również nasionami sosny, świerka i buka. Aby unieruchomić szyszkę i ułatwić sobie pracę, wciska ją w szczelinę kory lub rozwidlenie gałęzi. Szyszkę wciska łuskami do góry, wtedy dziobiąc na dół odgina z łatwością łuski i językiem wyciąga nasiona. W ciągu zaledwie minuty udaje mu się obrać całą szyszkę. Pustą szyszkę usuwa ze szczeliny jednym celnym uderzeniem dziobu. Ponieważ używa przez kilka tygodni tej samej szczeliny, wokół drzewa gromadzi się dosyć pokaźnych rozmiarów górka wyłuskanych szyszek. Taki charakterystyczny warsztat dzięcioła potocznie jest nazywany kuźnią. Zob. T. Kasperowicz, Dzięciot pracuje też w kuźni, https://www.lasy.gov.pl/pl/informacje/aktualnosci/dzieciol-tez-pracuje-w-kuzni [dostęp: 20.11.2018].

${ }^{51}$ T. Samojlik, Rozdział trzeci, w którym pojawia się legendarny Czort, [w:] T. Samojlik, Wilk Ambaras, s. 36: „(...) człowiek. Tropił i ścigał naszą watahę, polował we dnie i rozstawiał pu- 
Kolejnym, niemniej istotnym, celem edukacji ekologicznej jest prezentacja postaw życiowych wpisujących się w szeroko pojęte wychowanie.

Postawy zaprezentowane $w$ niniejszej bajce można podzielić na dwa rodzaje: na te, które podlegają krytyce oraz na te, które podlegają pochwale. Do postaw podlegających krytyce zaliczają się głównie negatywne postawy ludzi wobec wilków, na przkład przepędzanie ich z lasu, chodzenie w pobliżu wilczych nor, polowanie i zakładanie wnyków. Postawy podlegające w bajce pochwale można podzielić na dwa rodzaje: na postawy godne naśladowania, które reprezentują wilczy bohaterowie $\mathrm{w}$ stosunku do siebie ${ }^{52}$, a także na postawy afirmatywne, które reprezentują ludzie pomagający chronić wilki ${ }^{53}$ i szanujący środowisko naturalne.

Ponadto, w utworze podjęto dyskurs na temat negatywnego postrzegania wilków mającego swoje źródło w stereotypowych, a nawet skonfabulowanych informacjach zakorzenionych w ludowym i kulturowym przekazie na temat tych drapieżników ${ }^{54}$. Fabuła analizowanego utworu jest próbą odpowiedzi na trzy główne zarzuty ludzi wobec wilków, które często pojawiają się w dyskursie społecznym i na arenie polityczno-ekologicznej: na kwestię ataków wilków na ludzi, na wpływ polowań wilków na populację zwierzynę leśnej oraz na społeczne postrzeganie wilka jako zwierzęcia złego, zbędnego w ekosystemie.

Pierwszy zarzut dotyczy obaw na temat ataków wilków na ludzi. W treści bajki zaprezentowano kilka scen, w których dochodzi do interakcji człowiek wilk. W scenie przedstawionej w pierwszym rozdziale bajki ${ }^{55}$ wataha wyczuwa w lesie w pobliżu nory zapach człowieka, przenosi młode w kierunku zapasowej nory idąc okrężną drogą, aby zmylić ewentualnie podążającą za nimi

\footnotetext{
łapki w nocy, rozkopywał nory i wykradał nasze szczenięta. Prześladowania nie miały końca. Wydawało się, że nie ma dla nas ratunku, że wilki będą musiały zniknąć (...). Pewnej nocy prowadziłem watahę tropem łani. Zapach człowieka był ledwie wyczuwalny, za to wszechobecny. To osłabiło moją czujność. W pewnym momencie, przy kolejnym kroku, coś mocno schwyciło mnie za łapę. Zaplątałem się we wnyki! Wtedy poczułem ludzi. Zbliżali się, żeby sprawdzić swoje pułapki".

${ }_{52}$ Do postaw godnych naśladowania zalicza się m.in.: ochronę słabszych osobników przez osobniki silniejsze, ukazanie solidarności grupowej na przykładzie sceny, w której rodzeństwo wraca po zagubionego podczas śnieżycy Ambarasa. Zob. T. Samojlik, Rozdziat siódmy, w którym Ambaras sie gubi, [w:] T. Samojlik, Wilk Ambaras, s. 65-79.

${ }^{53}$ Do postaw afirmatywnych zaliczyć można m.in. scenę uwolnienia Ambarasa z wnyków przez zagubioną w lesie dziewczynkę czy scenę likwidacji przez wolontariuszy pułapek na wilki. Zob. T. Samojlik Rozdziat dziesiąty, w którym okazuje się, że... chociaż lepiej tego nie zdradzać za wcześnie, [w:] T. Samojlik, Wilk Ambaras, s. 97-112.

${ }^{54}$ Zaliczają się do nich negatywne przesłania wpisane w fabułę bajek, np. o Czerwonym Kapturku, a także kulturowe wyobrażenia na temat drapieżnej (jak choćby malarstwo Alfreda Wierusza-Kowalskiego, Napad wilków, 1890) i demonicznej natury wilków (wiara w likantropie).

${ }_{55}$ T. Samojlik, Rozdziat pierwszy, w którym pewien stabowity wilczek przychodzi na świat $i$ otrzymuje kłopotliwe imię, [w:] T. Samojlik, Wilk Ambaras, s. 7-17.
} 
nagonkę myśliwych ${ }^{56}$. Podobna scena ma miejsce $\mathrm{w}$ rozdziale dziewiątym ${ }^{57}$, kiedy to wilki uciekają przed myśliwymi ogradzającymi flandrami fragment lasu. Sytuacje przedstawione w bajce dają jednoznaczną odpowiedź na temat stosunku wilka do człowieka: wilk boi się obecności ludzi i schodzi mu z drogi, chcąc pozostać przez niego możliwie jak najdłużej niezauważonym. Przedstawienie w bajce wilka jako zwierzęcia bojącego się i uciekającego przed człowiekiem powoduje u dzieci rozwinięcie empatii i ujmowanie się za słabszym, potrzebującym pomocy człowiekiem czy zwierzęciem. Wilk żyjący na wolności nie postrzega człowieka w kategorii swojej przyszłej ofiary, nie istnieje więc realne zagrożenie ataków wilków na ludzi ${ }^{58}$.

Rzecz w tym, że człowiek nie jest naturalną ofiarą wilka. Gdyby wilki postrzegały ludzi jako swoje ofiary, wówczas ataki na nasz gatunek byłyby częste i kończyłyby się fatalnie. Zawsze jednak istnieje możliwość, że człowiek będzie naśladował zachowanie naturalnych ofiar wilków i kiedy taka osoba zacznie na przykład panicznie uciekać, może być zaatakowana. Jednak z mojego doświadczenia wynika, że wilki reagują na taką sytuację albo popłochem, albo traktują to jako zaproszenie do zabawy. Konkludując, poza wspomnianymi sytuacjami, których łatwo uniknąć i których należy unikać, nie ma żadnego powodu, aby bać się ataku ze strony wilka ${ }^{59}$.

Istnieją jednak sytuacje, w których może dojść do ataku wilka na człowieka. Robert Lyle w artykule, w którym stawia pytanie, czy wilki atakują ludzi ${ }^{60}$, opiera swoje doświadczenia na spotkaniach z wilkami żyjącymi w niewoli, w których strukturze stadnej występuje większe wyeksponowanie roli pary alfa $^{61}$, a wilki są oswojone $\mathrm{z}$ widokiem człowieka i są od niego zależne w kwe-

${ }^{56}$ R. Lyle, Czy wilki atakują ludzi? „Dzikie Życie” 1998, 2/44 https://dzikiezycie.pl/ archiwum/1998/luty-1998/czy-wilki-atakuja-ludzi [dostęp: 20.11.2018]: „Nie ma jednak poświadczonych dowodów na to, że wilki bronią swojego terytorium inaczej niż zaznaczając jego granice moczem lub warknięciami i poszczekiwaniem, natomiast jest kilka opisów, kiedy to naukowcy penetrowali wilcze nory, żeby policzyć lub sfotografować szczeniaki (zarówno w zamkniętych rezerwatach jak i na wolności). Rodzice protestowali zawsze wyłącznie głosem niezadowolenia".

${ }_{57}$ T. Samojlik, Rozdział dziewiąty, w którym występuja straszni ludzie i straszny Czort, a Ambaras nie wie, co myśleć, [w:] T. Samojlik, Wilk Ambaras,, s. 87-97.

${ }^{58}$ Istnieją jednak przypadki pseudoataków pojedynczych osobników wilków na ludzi, które są głównie formą wymuszenia od nich pokarmu. Takie ataki mają miejsce w przypadku wilka oswojonego przez ludzi, w którym dochodzą do głosu instynkty i zanikł strach przed człowiekiem oraz w przypadku hybrydy psa domowego i wilka wychowującego się wśród ludzi, wobec którego wykazuje większą agresję od psa. Ponadto, uciekający przed wilkami w panicznym strachu człowiek może przypominać wilkom zachowanie adekwatne do zachowania ich ofiar, gdyż to głównie ucieczka ofiary motywuje wilki do pościgu i ataku.

${ }^{59}$ R. Lyle, Czy wilki atakuja ludzi?

${ }^{60}$ Tamże.

${ }^{61}$ L.D. Mech, Alpha status, dominance, and division of labor in wolf packs, Canadian Journal of Zoology, 1999, 77, 8, s. 1196: „In captive packs, the unacquainted wolves formed dominance hierarchies featuring alpha, beta, omega animals, etc. With such assemblages, these dominance 
stiach zdobywania pokarmu. Lyle $\mathrm{w}$ momencie wkraczania na ogrodzone terytorium watahy spotkał się z nielicznymi przypadkami, kiedy samiec alfa potraktował go jako rywala. Było to spowodowane „(...) zadawaniem bólu, mimowolnym unieruchomieniem i zazdrością seksualną" ${ }^{62}$ samca alfy żyjącego w niewoli.

Kolejnym obecnym w bajce dyskursem $\mathrm{z}$ negatywnymi zarzutami wobec wilków jest problem ich drapieżności, a nawet rzekomej krwiożerczości względem upolowanej zwierzyny. W czwartym rozdziale bajki ${ }^{63}$ wilk Kulawiec (Czort) uczy wilczęta zasad przydatnych podczas czekającego je w przyszłości polowania. Na wątpliwość dotyczącą słuszności polowań przez wilki na inne zwierzęta, Kulawiec odpowiada wilczętom, że wataha poluje głównie na chore, osłabione osobniki.

Najważniejsze - tłumaczył - jest zwietrzenie ofiary. Po zapachu możecie poznać, co to za zwierzę, jak daleko od was się znajduje, a nawet, kiedy już nabierzecie doświadczenia, czy jest zdrowe czy może chore i osłabione i czy warto za nim podążać (...) Polujemy na chore zwierzęta, bo są one oczywiście wolniejsze i słabsze od tych w pełni sił. Wydaje mi się, że ma to też głębszy sens, bo jeśli my, wilki, szybko zajmiemy się chorym zwierzęciem, to jest szansa, że choroba się nie rozprzestrzeni. Dzięki nam przeżywają zwierzęta najsilniejsze ${ }^{64}$.

Przedstawienie w bajce wilka jako lekarza chorych zwierząt, który zapobiega roznoszeniu się chorób i skraca cierpienie innych zwierząt, doskonale oddziałuje na emocje młodych czytelników i umożliwia stworzenie sfery życia, do której mogą się one odwołać poprzez bezpośrednie doświadczenie. Izabela Wierzbowska w monografii na temat wilków cytuje, za Davidem Mechem oraz Petersonem ${ }^{65}$, podstawowe cechy potencjalnych ofiar wilków. Najczęściej zabijane są

samce kopytnych podczas okresu godowego, osobniki młode i stare, potomstwo młodszych rodziców, lżejsze osobniki o słabej kondycji, chore, osobniki osłabione pasożytnictwem kleszczy i tasiemców, osobniki zranione, kalekie, potomstwo niedożywionych lub starszych matek, osobniki mniej agresywne ${ }^{66}$.

labels were probably appropriate, for most species thrown together in captivity would usually so arrange themselves. In nature, however, the wolf pack is not such an assemblage. Rather, it is usually a family".

${ }^{62}$ R. Lyle, Czy wilki atakuja ludzi?

${ }^{63}$ T. Samojlik, Rozdział czwarty, w którym orzesznice spadaja z nieba, [w:] T. Samojlik, Wilk Ambaras, s. 41-46.

${ }^{64}$ Tamże, s. 41-42.

${ }^{65}$ L.D. Mech, O.R. Peterson, Wolf-prey relations, [w: ] Wolves. Behavior, ecology and conservation, red. L.D. Mech, L. Boitani, Chicago - London 2003, s. 131-160. Cyt. Za: I. Wierzbowska, Wilk jako drapieżnik. Taktyka towiecka, [w:] I. Wierzbowska, Wilk, s. 58.

${ }_{66}$ Tamże. 
Wilki są oportunistami i wolą polować na osobniki, które mogą z łatwością upolować. Ich obecność w ekosystemie powoduje naturalną selekcję wśród ssaków kopytnych, które stanowią dla nich bazę pokarmową. Wśród potencjalnych ofiar wilków przeżywają głównie osobniki najsilniejsze, co przedkłada się na przekazanie przez nich lepszej puli genowej swojemu potomstwu. W związku z powyższymi argumentami świadczącymi o ważnej roli, jaką odgrywają wilki w ekosystemie, nie powinny być uważane za szkodniki (za które uważają je ludzie przedstawieni w rozdziale dziewiątym bajki: Rozdział dziewiąty, w którym występuja straszni ludzie i straszny Czort, a Ambaras nie wie, co myśleć6 $)$.

Kolejną próbą odpowiedzi na zarzuty stawiane wobec wilków jest uważanie ich za zwierzęta z natury złe, co ma związek z symbolicznym i kulturowym sposobem postrzegania rzeczywistości ${ }^{68}$ przez ludzi. Takiego typu myślenie, związane często z hiperbolizacją łowieckich praktyk wilków, powoduje uznawanie wilka za zwierzę drapieżne. Drapieżność, kojarząca się z agresją i bezwzględnością zachowań, społecznie postrzegana jest jako cecha negatywna. Na zasadzie przeniesienia, dochodzi do utożsamienia czynów wilka (traktowanych jako złe) z samym zwierzęciem (traktowanym od tej pory jako synonim zła). Odpowiedzią na tego typu zarzuty jest zrozumienie, że zwierzę kieruje się głównie instynktem, który nie powinien być traktowany w kategorii subiektywności, lecz obiektywności działań, gdyż działaniami instynktownymi są „czynności i reakcje zwierząt (i ludzi), celowe, ale nieświadome i niewyuczone, oparte na wrodzonych mechanizmach psychicznych (...) ważne dla życia osobnika i gatunku" ${ }^{\prime \prime}$. Przedstawiony w ósmym rozdziale ${ }^{70}$ bajki dialog między ojcem a córką ${ }^{71}$ zbierającymi grzyby stanowi dla młodych czytelników przekaz na temat błędu logicznego w wystawianiu ocen subiektywnych obiektom, zjawiskom, które powinny być oceniane obiektywnie.

${ }^{67}$ T. Samojlik, Rozdziat dziewiąty, w którym występują straszni ludzie, s. 87-97.

${ }^{68}$ Wilk uważany jest za zwierzę złe, demoniczne. Zob. W. Kopaliński, Słownik mitów i tradycji kultury, Warszawa 1985, s. 1286.

${ }^{69}$ Hasło 'instynkt', [w:] Język polski. Wspótczesny stownik języka polskiego: A-N, red. B. Dunaj, Warszawa 2007, s. 531.

${ }^{70}$ T. Samojlik, Rozdział ósmy, w którym Łupinka przesypia porę zasypiania na zimę, a Niuch pokazuje, skąd wzięto się jego imię, [w:] T. Samojlik, Wilk Ambaras, s. 79-87.

${ }^{71}$ Tamże, s. 85: „- Wilki zdecydowanie wolą polować na inne zwierzęta. - Zjadają inne zwierzęta? To okropne! Dlaczego wilki muszą być takie złe? - Ależ one nie są złe. Taka już jest ich natura, że żywią się mięsem - ojciec dziewczynki pokiwał głową. - Tatusiu, a co to? - wykrzyknęła nagle dziewczynka. Oboje pochylili się nad znaleziskiem. - Oho, to jest wnyk. Pułapka na zwierzęta. Musiał ją tu zostawić kłusownik. To bardzo okrutna rzecz. Zobacz, jeśli zwierzę postawi tu nogę, ta stalowa linka zaciśnie się, sprawiając mu ogromny ból - opowiedział mężczyzna, a dziewczynka słuchała z szeroko otwartymi oczyma”. 
Warto jeszcze wspomnieć o biblioterapeutycznym wymiarze fabuły bajki traktującej o wilku Ambarasie, z którego przygodami i problemami młody czytelnik może się utożsamić. Tytułowy bohater bajki jest wilkiem, który nie spełnia oczekiwań większości członków swojego stada: jest słaby, chorowity, nie rozwija się tak szybko jak jego rodzeństwo, a przede wszystkim jest pozbawiony zmysłu węchu. W związku z tym, że świat przyrody rządzi się prawami, w którym przeżywają zazwyczaj najsilniejsze osobniki, wilk bez zmysłu powonienia (który jest niezbędny podczas polowania i umożliwia orientację $\mathrm{w}$ otaczającym świecie) wydaje się być skazany na porażkę wobec czekających go w przyszłości wyzwań. W związku z tym, na zasadzie kontrastu względem silniejszego rodzeństwa, odznaczającego się szybkością (Chyży) i siłą (Mocarny), tytułowy wilczek otrzymuje imię Ambaras. Pomimo że młody wilk nie jest tak sprawny fizycznie jak jego rodzeństwo, przewyższa ich intelektem, zmysłem obserwacji i został obdarzony zdolnością rozumienia ludzkiej mowy. Utożsamienie się czytelnika z bohaterem bajki może spowodować - na zasadzie odwrażliwienia ${ }^{72}$ - pokonanie własnych lęków związanych ze swoimi słabościami i kompleksami. Główny morał wpisany w fabułę tej bajki stanowi przesłanie, że każde życie na ziemi jest potrzebne i nie ma człowieka/istoty pozbawionej talentu, zdolności, trzeba tylko nauczyć się je dostrzegać w samym sobie oraz w innych ludziach.

Bajka Wilk Ambaras Tomasza Samojlika wpisuje się w nurt literatury promującej postawy proekologiczne $\mathrm{w}$ ramach prowadzonej edukacji ekologicznej. Zastosowanie lektury bajki w edukacji nieformalnej, ale również w edukacji formalnej, umożliwia wczesne zaznajomienie czytelnika ze światem natury, a poprzez ukazanie bioróżnorodności rodzimej fauny i flory, może wzbudzić w nim potrzebę ochrony przyrody i środowiska naturalnego. Poprzez zabieg uczynienia wilka głównym bohaterem bajki, lektura ta podejmuje ważny społecznie dyskurs dotyczący kontynuacji ochrony gatunkowej wilka jako gatunku priorytetowego a zarazem gatunku wyznacznikowego dla typowania obszarów Natura 2000. Dzięki lekturze bajki o wilku Ambarasie możliwe jest uwrażliwienie młodego czytelnika na kwestie ochrony wilka, co w przyszłości - w czekającym młodego czytelnika dorosłym życiu - może zaowocować u niego wiedzą i większą świadomością ekologiczną na tematy ważne z punktu widzenia społeczno-ekologicznego. Cele te mogą zostać spełnione głównie za sprawą obecnej w utworze idei demitologizacji/obalania negatywnych mitów na temat wilków, które stanowią pierwszy krok w stronę zmiany optyki patrzenia na te zwierzęta jako na gatunek ważny ekosystemowo.

\footnotetext{
${ }^{72}$ M. Rybczyńska, Rola bajki w XXI wieku, s. 267.
} 


\section{BIBLIOGRAFIA}

\section{Źródła tradycyjne}

Buczyńska I., Chojecka K., Rozpądowska E., Przedszkolaki bliżej natury, Wychowanie w Przedszkolu, 1999, 7.

Budniak A., Edukacja społeczno-przyrodnicza dzieci w wieku przedszkolnym i młodszym wieku szkolnym, Oficyna Wydawnicza Impuls, Kraków 2014.

Domka L., Dialog z przyroda w edukacji dla ekorozwoju, Wydawnictwo Naukowe PWN, Warszawa - Poznań 2001.

Fiszer M., Metody i formy w edukacji ekologicznej dzieci w wieku przedszkolnym, Prace Naukowe. Pedagogika, 2002, 11.

Hasło 'bajka', [w:] Słownik terminów literackich, red. J. Sławiński, Zakład Narodowy im. Ossolińskich, Wrocław - Kraków 1998.

Hasło 'instynkt', [w:] Język polski. Współczesny stownik języka polskiego: A-N, red. B. Dunaj, Langenscheidt, Warszawa 2007.

Hasło 'wilk', [w:] W. Kopaliński, Stownik mitów i tradycji kultury, Państwowy Instytut Wydawniczy, Warszawa 1985.

Jadach B.B., Kolorowe kosze. Bajki o tematyce ekologicznej, Wydawnictwo Fraszka Edukacyjna, Warszawa 2014.

Jakimiuk S., Stowo od wydawcy, [w:] T. Samojlik, Wilk Ambaras, Agencja Wydawnicza EkoPress, Fundacja WWF Polska, Warszawa 2012.

Jarzyńska I., Edukacja ekologiczna w szkolnictwie szkolnym, Edukacja Elementarna w Teorii i Praktyce: Kwartalnik dla nauczycieli, 2008, 1-2.

Jędrzejewska-Wróbel R., Florka - z pamiętnika ryjówki, Wydawnictwo Literatura, Łódź 2008. Kalinowska A., Ekologia - wybór przyszłości, Editions Spotkania, Warszawa 1993.

Kopeć E., Znaczenie i rola edukacji ekologicznej w nauczaniu początkowym, [w:] Edukacja ekologiczna. Wybrane problemy, red. M.K. Terlecka, Wydawnictwo Armagraf, Krosno 2014.

Kowolik P., Wptyw bajki i baśni na dzieci w edukacji wczesnoszkolnej: szkic teoretyczny, Nauczyciel i Szkoła, 2004, 3-4(24-25).

Krajowy standard kompetencji zawodowych Ministerstwa Pracy i Polityki Społecznej, Centrum Rozwoju Zasobów, Warszawa 2013.

Louv R., Ostatnie dziecko lasu, Grupa Wydawnicza Relacja, Warszawa 2014.

Mech L.D., Peterson O.R., Wolf-prey relations, [w: ] Wolves. Behavior, ecology and conservation, red. L.D. Mech, L. Boitani, The University Chicago Press, Chicago - London 2003.

Mech L.D., Alpha status, dominance, and division of labor in wolf packs, Canadian Journal of Zoology, 1999, 77, 8.

Niziołek R., Promocja ekologii wśród dzieci i młodzieży na przykładzie programu telewizyjnego «Załoga Eko», Studia i Materiały CEPL w Rogowie, 2015, 17, 43(2).

Nowak S., Mysłajek R., Okarma H., Śmietana W., Analiza dotychczasowych rodzajów i rozmiaru szkód wyrządzanych przez wilki (Canis lupus) oraz stosowanych metod rozwiązywania sytuacji konfliktowych, Instytut Ochrony Przyrody PAN, 2005 (manuskrypt).

Okarma H., Gula R., Brewczyński P., Działania niezbędne dla realizacji celów strategii. Dziatania informacyjne/edukacyjne/komunikacyjne, [w:] H. Okarma, R. Gula, P. Brewczyński, Program ochrony wilka Canis lupus w Polsce - Projekt Krajowa strategia ochrony wilka warunkująca trwałość gatunku w Polsce, Szkoła Główna Gospodarstwa Wiejskiego, Warszawa 2011.

Okarma H., Gula R., Brewczyński P., Konflikt wilków z człowiekiem. Konflikt z hodowla zwierząt gospodarskich, [w:] H. Okarma, R. Gula, P. Brewczyński, Program ochrony wilka Ca- 
nis lupus w Polsce - Projekt Krajowa strategia ochrony wilka warunkująca trwałość gatunku w Polsce, Szkoła Główna Gospodarstwa Wiejskiego, Warszawa 2011.

Olaczek R., Stownik szkolny. Ochrona przyrody i środowiska, WSiP, Warszawa 1999.

Pawłowski A., Rozwój zrównoważony - idea, filozofia, praktyka, Monografie Komitetu Inżynierii Środowiska PAN, 2008, 51, Lublin.

Przez edukację do zrównoważonego rozwoju. Narodowa strategia edukacji ekologicznej, Ministerstwo Środowiska, Warszawa 2001.

Rybczyńska M., Rola bajki w XXI wieku w stymulowaniu rozwoju dziecka w wieku wczesnoszkolnym 7-10 lat, Kultura i Historia, 2017, 32.

Samojlik T., Rozdziat czwarty, w którym orzesznice spadaja z nieba, [w:] T. Samojlik, Wilk Ambaras, Agencja Wydawnicza EkoPress, Fundacja WWF Polska, Warszawa 2012.

Samojlik T., Rozdziat dziesiaty, w którym okazuje się, że... chociaż lepiej tego nie zdradzać za wcześnie, [w:] T. Samojlik, Wilk Ambaras, Agencja Wydawnicza EkoPress, Fundacja WWF Polska, Warszawa 2012.

Samojlik T., Rozdział dziewiąty, w którym występują straszni ludzie i straszny Czort, a Ambaras nie wie, co myśleć, [w:] T. Samojlik, Wilk Ambaras, Agencja Wydawnicza EkoPress, Fundacja WWF Polska, Warszawa 2012.

Samojlik T., Rozdziat ósmy, w którym Łupinka przesypia porę zasypiania na zime, a Niuch pokazuje, skąd wzięto się jego imię, [w:] T. Samojlik, Wilk Ambaras, Agencja Wydawnicza EkoPress, Fundacja WWF Polska, Warszawa 2012.

Samojlik T., Rozdziat pierwszy, w którym pewien stabowity wilczek przychodzi na świat $i$ otrzymuje kłopotliwe imię, [w:] T. Samojlik, Wilk Ambaras, Agencja Wydawnicza EkoPress, Fundacja WWF Polska, Warszawa 2012.

Samojlik T., Rozdziat siódmy, w którym Ambaras się gubi, [w:] T. Samojlik, Wilk Ambaras, Agencja Wydawnicza EkoPress, Fundacja WWF Polska, Warszawa 2012.

Samojlik T., Rozdział trzeci, w którym pojawia się legendarny Czort, [w:] T. Samojlik, Wilk Ambaras, Agencja Wydawnicza EkoPress, Fundacja WWF Polska, Warszawa 2012.

Samojlik T., Wilk Ambaras, Agencja Wydawnicza EkoPress, Fundacja WWF Polska, Warszawa 2012.

Samojlik T., Żubr Pompik. Kolory jesieni, Media Rodzina, Poznań 2016.

Samojlik T., Żubr Pompik. Letni zmierzch, Media Rodzina, Poznań 2016.

Samojlik T., Żubr Pompik. Tropy na śniegu, Media Rodzina, Poznań 2016.

Samojlik T., Żubr Pompik. Zapach wiosny, Media Rodzina, Poznań 2016.

Samojlik T., Bagienny toś, Media Rodzina, Poznań 2017.

Samojlik T., Plan bobra, Media Rodzina, Poznań 2017.

Samojlik T., Tajemnica rzeki, Media Rodzina, Poznań 2017.

Samojlik T., Rodzina borsuków, Media Rodzina, Poznań 2018.

Terlecka M.K., O edukacji ekologicznej w Polsce, [w:] Edukacja ekologiczna. Wybrane problemy, red. M.K. Terlecka, Wydawnictwo Armagraf, Krosno 2014.

Tuszyńska L., Edukacja ekologiczna dla nauczycieli i studentów, Wyższa Szkoła Pedagogiczna Towarzystwa Wiedzy Powszechnej, Warszawa 2006.

Wajchman S., Borzyszkowski W., Matulewski P., Rola edukacji przyrodniczo-leśnej w kształtowaniu proekologicznych postaw społeczeństwa, [w:] Edukacja ekologiczna. Wybrane problemy, red. M.K. Terlecka, Wydawnictwo Armagraf, Krosno 2014.

Wierzbicka A., Ciemnoczołowska O., Dłużak W., Flies M., Zawadzki M., Do kogo kierować edukację? Wiedza społeczeństwa na temat wilków w pótnocno-zachodniej Polsce, Studia i Materiały CEPL w Rogowie, 2016, 18, 47(2).

Wierzbowska I., Rozmieszczenie wilków w Polsce i na świecie oraz środowisko życia, [w:] I. Wierzbowska, Wilk, Fundacja Wspierania Inicjatyw Ekologicznych, Kraków 2010. 
Wierzbowska I., Wilk jako drapieżnik. Taktyka łowiecka, [w:] I. Wierzbowska, Wilk, Fundacja Wspierania Inicjatyw Ekologicznych, Kraków 2010.

Żurakowski B., Wartości estetyczne w literaturze dla dzieci, [w:] Wartości w świecie dziecka i sztuki dla dzieci, red. M. Tyszkowa, B. Żurakowski, PWN, Warszawa - Poznań 1984.

\section{Źródła elektroniczne}

Kasperowicz T., Dzięcioł pracuje też w kuźni, https://www.lasy.gov.pl/pl/informacje/aktualnosci/dzieciol-tez-pracuje-w-kuzni [dostęp: 20.11.2018].

Lyle R., Czy wilki atakują ludzi?, „Dzikie Życie” 1998, 2/44 https://dzikiezycie.pl/archiwum/1998/luty-1998/czy-wilki-atakuja-ludzi [dostęp: 20.11.2018].

Status prawny wilka, Stowarzyszenie dla Natury „Wilk” http://www.polskiwilk.org.pl/ status-prawny-wilka [dostęp: 20.11.2018].

Ślązak A., Raport: wilki w Polsce Zachodniej mają się coraz lepiej, PAP:

http:/ / naukawpolsce.pap.pl/aktualnosci/news\%2C408470\%2Craport-wilki-w-polsce-zachodniej-maja-sie-coraz-lepiej.html [dostęp: 20.11. 2018]. 